\title{
Destination Manual Worker or Clerk? Ethnic Differences in the Transition from School to Work
}

\author{
By Anne Hartung and Karel Neels*
}

\begin{abstract}
Investigating the transition from education to employment among school leavers from different ethnic backgrounds, this paper focuses on the structural integration of ethnic minorities through the labour market. Distinguishing blue collar and white collar employment as destination states, proportional hazards models for competing risks are estimated on the basis of the German Socio-Economic Panel (GSOEP). The results reveal that the factors influencing the transition to employment differ considerably depending on the type of employment. The study argues that a sole indicator of unemployment is insufficient to draw conclusions on the integration of ethnic minorities in the labour market.
\end{abstract}

JEL Classification: J64, J24, J42

\section{Introduction}

Empirical research indicates that low-skilled ethnic minorities ${ }^{1}-$ depending on their origin - face great socio-economic disadvantages in many countries (Castles / Miller, 2003; OECD, 2005; Schultz, 1998). While employment is often seen as a key to integration ${ }^{2}$, the unemployment of non-EU nationals in

* This study would not have been possible without the Bourse Formation de la Recherche (BFR) from the Luxembourg Fonds National de la Recherche (FNR). We would like to thank Ingrid Tucci (DIW Berlin) and Jacques Brosius (CEPS / INSTEAD) for invaluable discussions and helpful suggestions on earlier versions of this paper as well as the participants of the IUSSP Scientific Panel on the Integration of Migrants, the $4^{\text {th }}$ International Young Scholars SOEP Symposium and the $8^{\text {th }}$ International SOEP User Conference 2008. We are particularly grateful for the suggestions and comments made by the anonymous reviewers.

1 Ethnic minority refers here to "a collectivity within a larger society having $[\ldots]$ common ancestry" (Schermerborn, 1970) and may thus be compared to the concept 'migration background' as often referred to in the German context.

2 Integration is understood here as the inclusion of populations into existing social structures (Heckmann, 1997). 
Germany is on average about twice as high as that of EU nationals (Council of the European Union, 2004, 101; see also Kalter/Granato, 2002; Kogan, 2004). However, failing to differentiate between different sectors, comparisons of overall indicators of unemployment reveal only part of the labour market inequalities and are thus "little meaningful" (Sachverständigenrat, 2004). Taking this into account, the present paper not only identifies factors accounting for ethnic differences in the transition from education to employment but also distinguishes transitions to white collar and blue collar employment. Out of the few detailed studies on Germany in this field (Bender/Seifert, 2000; Kogan/Walter, 2003; Uhlendorff / Zimmermann, 2006), Kogan's rich study (2004) examines exemplarily unemployment dynamics among different ethnic groups - yet only for men and a rather short period (1995-2000). Also, repeated unemployment spells are pooled although it might be worthwhile from a life course perspective to distinguish particular events such as finding a job after leaving the educational system. Finally, in comparison to analyses that look merely at unemployment, the present study may better reflect the true length of the transition between school and employment by extending this definition.

The paper is organised as follows. Section 2 reviews the pertinent literature, followed by sections describing the data and the methodology used. Section 5 presents the results and Section 6 concludes.

\section{Literature Review}

Several theoretical approaches have attempted to explain (ethnic) differences in labour market outcomes. ${ }^{3}$ From the perspective of human capital theory, differences in labour market outcomes are due to different levels of education and training (Rosen, 1998, 681). Not only schooling abroad (and lacking recognition of degrees) but also language barriers may prevent newly arrived immigrants from obtaining a job appropriate to their educational background (Berman / Lang/Siniver, 1999; Chiswick/Lee/Miller, 2002; Schmid, 2001). Residence in the host society helps to accumulate host-country specific human capital - "age of immigration matters" (Becker, 1993; Schaafsma / Sweetman, 2001). Although ethnic labour market inequalities are largely due to human capital (Kalter / Granato, 2002), critics find unexplained differences after controlling for human capital (Phalet / Swyngedouw, 2003; Rooth / Ekberg, 2003). It is moreover crucial to shift the focus of the analysis to differential access to education in those cases where human capital can actually account for the observed labour market differences. ${ }^{4}$

\footnotetext{
3 Also discrimination theories should be acknowledged here but are not focused here as remains difficult to relate the observed inequalities to discrimination with the applied research design.
} 
Theories of labour market segmentation claim that particular groups concentrate in specific labour market segments, or, that the opportunities for these groups are confined to specific segments. In the primary (or internal) sector, firms invest into their employees in the form of firm-specific on-the-job training and offer higher wages, tenure and internal promotion opportunities in order to retain their employees. This leads to stable employment (Cain, 1998; Doeringer / Piore, 1971). In contrast, jobs in the secondary (or external) sector are characterised by low wages, poorer career opportunities, instable or precarious contracts and are often coupled with periods of unemployment. Migrants may not have access to internal markets due to lacking training on the job and skill specificity. In particular temporary workers may then accept more frequently less desirable working conditions (Bonacich, 1975). The question is whether the length of stay in the host country can (partially) account for this differential access.

Finally, a number of authors argue that families maximise utility across generations and that structural outcomes must also be seen from an intergenerational perspective (Becker/Tomes, 1979; Borjas, 1992). Looking at labour market outcomes of the children of immigrants in Denmark, Nielsen et al. (2001) find that parental capital (and neighbourhood effects) has a great impact on the educational attainment and to a lesser extent on the waiting time for the first job. This is important given that the first generation immigrants who came to Germany in the frame of guest worker schemes have a very different educational profile than native Germans (Münz/Ulrich, 2000; Ray, 2004). Turkish guest workers for instance came to a large extent from rural areas and with (very) low education levels, let alone German language skills. In the analysis, the educational attainment of the father is introduced in order to map the effects of parental background on ethnic differentials in the transition to employment.

\section{Data}

The analysis is based on the 1984-2006 waves of the German SocioEconomic Panel (SOEP), which oversamples persons with a migration background (Haiskens-Denew/Frick, 2005). The definition of the starting point, the target event, and the metric for measuring time are of substantive importance for duration analysis (Singer/Willett, 2003, 310). The date leaving school represents the starting point at which individuals enter the risk set for the transition to employment. For persons entering vocational training or mili-

\footnotetext{
4 School leavers with lower degrees (Hauptschule/Realschule) have poorer chances to enter apprenticeships in the banking, insurance or tourism sector whereas ethnic minorities are overrepresented among school leavers without any or low degrees (Sachverständigenrat für Zuwanderung und Integration, 2004, 264; Barabasch, 2005).
} 
tary service the entry into the risk set was postponed until the end of these spells. ${ }^{5}$ The transition period does not only include 'classic unemployment' but also bridging periods (mini-jobs, short work hours, gaps, and activities other than work or inactivity). ${ }^{6}$ The sample also includes direct transitions to work, i.e. those observations without gap between school and employment (see Table 1). Spells or gaps of up to three months between two different education periods were recoded as education, while absence from the educational system for three months or more was regarded as job search. Gaps of one month or more are considered as exits from the labour market. The event - or transition - of interest is the move from the initial state of education or unemployment to full-time or part-time employment. Persons moving into inactivity or a new spell of education have been considered as censored. The transition to the first employment is a non-repeatable event (Blossfeld / Golsch / Rohwer, 2007). The observation period spans 276 months. Given that the duration between graduation/ leaving school and the event of finding a job is measured in months, continuous-time event-history methods are applied.

A few limitations should be pointed out here. First, looking at blue and white collar employment excludes self-employed persons, civil servants and interns. Secondly, inaccuracies occur where the monthly labour market status does not coincide with the labour market status of the time of the survey. Possible job changes between these two points of time had to be ignored.

The sample used for the analysis consists of 5,507 cases either directly finding employment or entering a transition period between graduation/school leaving and employment. Combining nationality and country of origin, 4,372 German, 373 Turkish, 158 (Ex-) Yugoslavians, 306 Mediterranean, 96 German re-settlers, 109 Eastern Europeans and 93 school leavers from other ethnic backgrounds could be identified. Germans were defined in a narrow sense (German nationality and country of origin), whereas ethnic Germans (Spätaussiedler) were defined as German nationals with (Ex-)Russian countries as origin. The other ethnic groups comprise persons with foreign nationality or country of origin.

\footnotetext{
5 Persons leaving directly after school into inactivity were excluded as they do not enter the labour market. However, important to remark is ethnic minorities more frequently leave into inactivity (see Table 1), and in particular women. While among Germans for instance $71 \%$ of the persons entering inactivity directly after school are women, $92 \%$ of the Turkish and even $100 \%$ of the German re-settlers are women.

6 Unemployment alone may not capture the whole extent of the transition from education to employment in Germany. In order to be eligible for unemployment support from the government, twelve months of employment prior to registration is required. There is no particular provision for school leavers. (However, work which has been part of an apprenticeship is recognised to some extent.) The same rules apply to nonnationals.
} 


\section{Methodology}

The durations and transitions are modelled using hazard models. The continuous-time hazard function $\lambda(t)$ is a (time-specific failure) rate measuring the "conditional probability of event occurrence per unit of time" (Singer/ Willet, 2003, 474):

$$
\lambda(t)=\lim _{\Delta t \rightarrow 0+} \frac{\operatorname{pr}(t \leq T<t+\Delta t \mid t \leq T)}{\Delta t}
$$

with $T$ denoting the failure time (Cox, 1972, 187). The effects of the covariates are estimated using the Cox proportional hazards model:

$$
h\left(t_{i j}\right)=h_{0}\left(t_{j}\right) e^{\beta_{1} X_{1 i j}+\beta_{2} X_{2 i j}+\ldots+\beta_{k} X_{k i j}}
$$

with $h_{0}\left(t_{j}\right)$ representing an unspecified baseline hazard function. ${ }^{7}$ The hazard ratios $^{8}$ estimating the effects of variables can easily be derived from above:

$$
\frac{h\left(t_{i j}\right)_{\text {COVARIATE }=1}}{h\left(t_{i j}\right)_{\text {COVARIATE }=0}}=\frac{h_{0}\left(t_{j}\right) e^{\beta_{1}}}{h_{0}\left(t_{j}\right)}=e^{\beta_{1}} .
$$

Equations 2 and 3 imply that the groups defined by the covariates in the model display hazard functions with an identical general shape, i.e. hazards are assumed to be proportional (Blossfeld et al., 2007). No time-varying effects have been introduced in the model. ${ }^{9}$

\section{Results}

Transitions to work take rather long: while after six months still $52 \%$ remain in unemployment, about $43 \%$ wait 12 months and longer. But more important are the ethnic differences. Germans for instance seem to more often directly find a job compared to other ethnic groups (Table 1). Furthermore, the Kaplan Meier survival curve in Figure 1 shows that the ethnic groups behave differently - and to some extent even reverse - when looking at blue and white

\footnotetext{
7 Throughout the analysis the Breslow method for handling tied events has been implemented.

8 Hazard ratios of greater than 1 relate to a positive effect, while those smaller than 1 refer to negative effects (i.e. higher transition rates for the transition from unemployment to work and shorter durations).

9 However, the effects of several covariates in the model could plausibly vary over time. The results from a non-proportional model can be obtained from the authors. Finally, it is assumed for this study that all heterogeneity is observed and can be ascribed to the covariates in the model.
} 
collar work separately. Still, this fact remains unrevealed in the graph on the transition to work in general (Figure 1a).

Similarly, introducing ethnicity into a proportional hazards model for the transition from education to work in general (blue or white collar work) yields significant differences only for the Mediterranean minority who seem to make faster transitions to employment compared to Germans (Table 2, Model 0). According to segmentation theories, however, distinguishing different types of employment may well unveil important ethnic differences in the transition to employment. Dichotomising labour market outcomes, two cause-specific hazard models for the transition to blue collar and for the transition to white collar employment are fitted (Table 2). ${ }^{10}$ Indeed, the competing risk model reveals a different picture with greater ethnic differences. With hazards for taking up blue collar work that are 1.8 to 2.4 times higher for ethnic minorities than for German natives, Model 1a demonstrates that the three largest ethnic minorities as well as German re-settlers differ significantly from German natives at first sight. Turks also seem disadvantaged with regard to white collar employment (Model 2a). The hazards for Turks to make the transition to white collar employment are extremely low compared to German natives ( $71 \%$ less), indicating that only few Turks take up white collar jobs compared to German natives.

The competing risk models indicate that ethnic groups enter the labour market segments with different speeds. Additional models are fitted to address the question of whether these differences can be accounted for by relevant background characteristics such as human capital, parental capital and socio-demographic variables.

Blue collar employment. Regarding ethnic differences in relation to the above mentioned theories, it is remarkable that even in Model 1b, which does control for some background variables, ethnic differences still remain substantial although less pronounced. Age, sex, education and first job ${ }^{11}$ as well as its interaction with education (controlling for historical period and region) apparently cannot account for the higher hazards of ethnic minorities to leave into blue collar employment. Including the age of immigration (Model 1c) renders the effect of ethnicity sufficiently small as to become insignificant. The length of stay in the host country has a positive effect as anticipated. Only those immigrants who immigrated later than the compulsory school age (age 6 or older) have a significantly different hazard rate than German natives.

The inclusion of all variables that represent human capital in Model 1c further contributes to explaining the differences in the group-specific hazard

10 Blue collar work comprises unskilled, semi-skilled, skilled work, foremen and master craftsmen whereas white collar work includes industrial foremen, unskilled, semi-skilled, qualified, professional and managerial labour.

11 This dummy indicates whether a person leaves the educational system for the very first job in his / her career. 
rates. Vocational education and higher secondary education degrees are associated with faster transitions to blue collar employment. Labour market experience on the other hand seems to have negative impact; transitions to the first job are made almost three times quicker. The final model also includes parental background characteristics. While it does not make a difference whether the father has secondary education or less, the results show that the higher the education of the father, the lower the hazards of making the transition to blue collar work. ${ }^{12}$ This is similar to the effect of the individual's own education and degree attainments.

White collar employment. From the right side of the table with the results of the second set of Cox regressions, it is first of all striking that the effects of the covariates are very different for the transition to white collar employment. Similar to the transition to blue collar work, however, is that the initial ethnic differences found in Model 2a decrease when taking into account basic background characteristics (Model 2b) but fail to disappear. Turkish minorities still differ significantly from Germans. Again, taking age of immigration into account in Model 2c, ethnic differences as measured using nationality decline further, to the point where the differences become insignificant as a result of the small sample size. In contrast to the findings on blue collar employment, age of immigration has no effect on the transition to white collar employment. With regard to blue collar employment it can be concluded that newcomers who arrive later in life are much more likely than young newcomers to become employed in manual jobs, suggesting their limited access to other segments of the labour market.

Similar to the transition to blue collar work, school leavers entering the first job make much faster transitions to white collar jobs than previously employed individuals. In modelling the transition to white collar work, the marital status is also relevant. Being married increases the hazards in general by $56 \%$, while it reduces the chances for women to get hired in the white collar sector $(1.564 * 0.446=0,698)$. Having children reduces the hazard of finding a white collar post considerably, for both sexes. With regard to education, gender differences can also be found: higher education increases the hazards for white collar employment up to three times for the general population, but the effect is only half that size for women $(2.891 * 0.546=1.579)$. Note, however, that there is a large positive main effect for women (2.700), which can compensate for these effects. The reverse is the case for the lowest levels of education. While it decreases the chances for white collar employment in general, women still make quicker transitions than men.

Finally, it is interesting that the parental background is not relevant in the transition to white collar jobs, in contrast to what has been found for the blue

12 The mother's education was also significant but not when both variables were included in the model. 
collar sector. Direct intergenerational dependencies cannot be confirmed for white collar employment.

\section{Conclusion}

In contrast to similar studies on the transition from school to work, the transition period in this study does not only include classical unemployment durations but also periods with small jobs, etc. In line with theories of labour market segmentation, different destination states have been taken into account. Investigating these transition patterns among young school leavers from different ethnic backgrounds, the characteristics that are associated with transitions into blue collar work are identified as well as characteristics that foster transitions into white collar employment. Striking from the analysis is that ethnic differences in labour market outcomes are largely underestimated when looking at an overall indicator (such as unemployment rates or durations) as different mechanisms may cancel each other out. This finding conforms to results obtained for Turkish and Moroccan immigrants in Belgium (Neels, 2000; Neels / Stoop, 2000). The distinction in terms of type of employment reveals additional ethnic differentiation in labour market outcomes. While these differences cannot be fully explained by basic socio-demographic characteristics, they largely disappear when taking human capital and parental background characteristics into account.

The mechanisms behind the transition, however, differ between blue and white collar employment. For the transition to blue collar employment, ethnic differences were in part due to individuals' age at immigration. While foreign nationals who largely took part in the German education system are not significantly different from German natives, ethnic minorities who immigrated later in life are more likely to become employed as blue collar workers. Whether this reflects mainly language skills and knowledge about the host country requires further research. Remarkable is that the parental background is relevant for the transition to blue collar work but not for the transition to the white collar sector.

Based on these results it seems that breakdowns of unemployment indicators (unemployment rates or durations) are insufficient to draw conclusions on integration. More detailed analyses which focus on sector of employment in tandem with socio-economic characteristics are necessary in order to conclude on the labour market integration of ethnic minorities.

\section{References}

Barabasch, A. / Lakes, R. D. (2005): School-to-Work Transitions in East Germany: Challenges of a Market Society, Career and Technical Education Research 30 (1), 3-24. 
Becker, G. S. (1993): Human Capital - A Theoretical and Empirical Analysis with Special Reference to Education, Chicago / London.

Becker, G. S. / Tomes, N. (1979): An Equilibrium Theory of the Distribution of Income and Intergenerational Mobility, Journal of Political Economy 87 (6), 1153 - 1189.

Bender, S. / Seifert, W. (2000): Zur beruflichen und sozialen Situation der in Deutschland lebenden Ausländer, in: R. Alba et al. (Eds.), Deutsche und Ausländer: Freunde, Fremde oder Feinde?, Wiesbaden.

Berman, E. / Lang, K. / Siniver, E. (1999): Language-Skill Complementary: Returns to Immigrant Language Acquisition, MFIER Working Paper (99.04).

Blossfeld, H.-P./Golsch, K./Rohwer, G. (2007): Event History Analysis with Stata, London.

Bonacich, E. (1975): A Theory of Ethnic Antagnonism: The Split-Labour Market, American Sociological Review 37 (5), 547 - 559.

Borjas, G. J. (1992): Ethnic Capital and Intergenerational Mobility, The Quarterly Journal of Economics 107 (1), $123-150$.

Cain, G. G. (1998): Segmented labour markets, in: J. Eatwell / M. Milgate/ P. Newman (Eds.), The New Palgrave. A Dictionary of Economics (Vol. 4), London, 285-287.

Castles, S. / Miller, M. J. (2003): The Age of Migration: international population movements in the modern world, Basingstoke.

Chiswick, B. R. / Lee, Y. L./Miller, P. W. (2002): Longitudinal Analysis of Immigrant Occupational Mobility: A Test of the Immigrant Assimilation Hypothesis, IZA Discussion Paper 452.

Council of the European Union (2004): Joint Employment Report 2003/2004, Brussels: Council of the European Union.

Cox, D. R. (1972): Regression Models and Life-Tables, Journal of the Royal Statistical Society, Series B (Methodological), 34 (2), 187-220.

Doeringer, P. B. / Piore, M. J. (1971): Internal Labor Markets and Manpower Analysis, Lexington, Massachusetts.

Haiskens-DeNew, J. P./Frick, J. R. (2005): DTC. Desktop Companion to the German Socio-Economic Panel (SOEP), Berlin: DIW Berlin.

Kalter, F. / Granato, N. (2002): Ethnic Minorities' Education and Educational Attainment: The Case of Germany. MZES Working Papers 58.

Kogan, I. (2004): Last Hired, First Fired? The Unemployment Dynamics of Male Immigrants in Germany, European Sociological Review 20 (5), 445-461.

Kogan, I. / Walter, M. (2003): School-to-Work Transitions in Europe: Analyses of the EU LFS Ad Hoc Module, Mannheim.

Münz, R./ Ulrich, R. (2000): Die ethnische und demographische Struktur von Ausländern und Zuwanderern in Deutschland, in: R. Alba et al. (Eds.), Wiesbaden.

Neels, K. (2000): Education and the Transition to Employment. Young Turkish and Moroccan Adults in Belgium, in: R. Lesthaeghe (Ed.), Communities and Generations: Turkish and Moroccan Populations in Belgium, Brussel, Vrije Universiteit Brussel, $243-278$ 
Neels, K. / Stoop, R. (2000): Reassessing the Ethnic Gap. Employment of Younger Turks and Moroccans in Belgium, in: R. Lesthaeghe (Ed.), Communities and Generations: Turkish and Moroccan Populations in Belgium, Brussel, Vrije Universiteit Brussel, $279-320$.

Nielsen, H. S. / Rosholm, M. / Smith, N. / Husted, L. (2001): Intergenerational Transmissions and the School-to-Work Transition of $2^{\text {nd }}$ Generation Immigrants, IZA Discussion Paper 296.

OECD. (2005): Trends in International Migration: SOPEMI 2004 Edition: OECD.

Phalet, K. / Swyngedouw, M. (2003): Measuring immigrant integration: the case of Belgium, Studi Emigrazione / Migration Studies, XL (152), 773 - 803.

Ray, B. (2004): Practices to Promote the Integration of Migrants into Labour Markets, HWWA Hamburg Migration Research Group, paper prepared for the European Commission, DG Employment and Social Affairs.

Rooth, D.-O. / Ekberg, J. (2003): Unemployment and earnings for second generation immigrants in Sweden. Ethnic background and parent composition, Journal of Population Economics (16), $787-814$.

Rosen, S. (1998): Human capital, in: J. Eatwell/M. Milgate/P. Newman (Eds.), The New Palgrave. A Dictionary of Economics (Vol. 2), London, 681 - 690.

Sachverständigenrat für Zuwanderung und Integration (Ed.) (2004): Migration und Integration - Erfahrungen nutzen, Neues wagen: http://www.dstgb.de/, 12/11/2007.

Schaafsma, J./Sweetman, A. (2001): Immigrants Earnings: Age at Immigration Matters, Canadian Journal of Economics 34, 1066-1099.

Schermerborn, R. A. (1970): Comparative Ethnic Relations: A Framework for Theory and Research. Chicago.

Schmid, C. (2001): Educational Achievement, Language-Minority Students, and the New Second Generation. Sociology of Education 74 (0, Extra Issue), $71-87$.

Schultz, P. (1998): Immigrant quality and assimilation: A review of the US literature, Journal of Population Economics (11), 239-252.

Singer, J. D. / Willet, J. B. (2003): Applied Longitudinal Data Analysis, Oxford.

Uhlendorff, A. / Zimmermann, K. F. (2006): Unemployment Dynamics among Migrants and Natives, DIW Discussion Papers 617. 
Destination Manual Worker or Clerk?

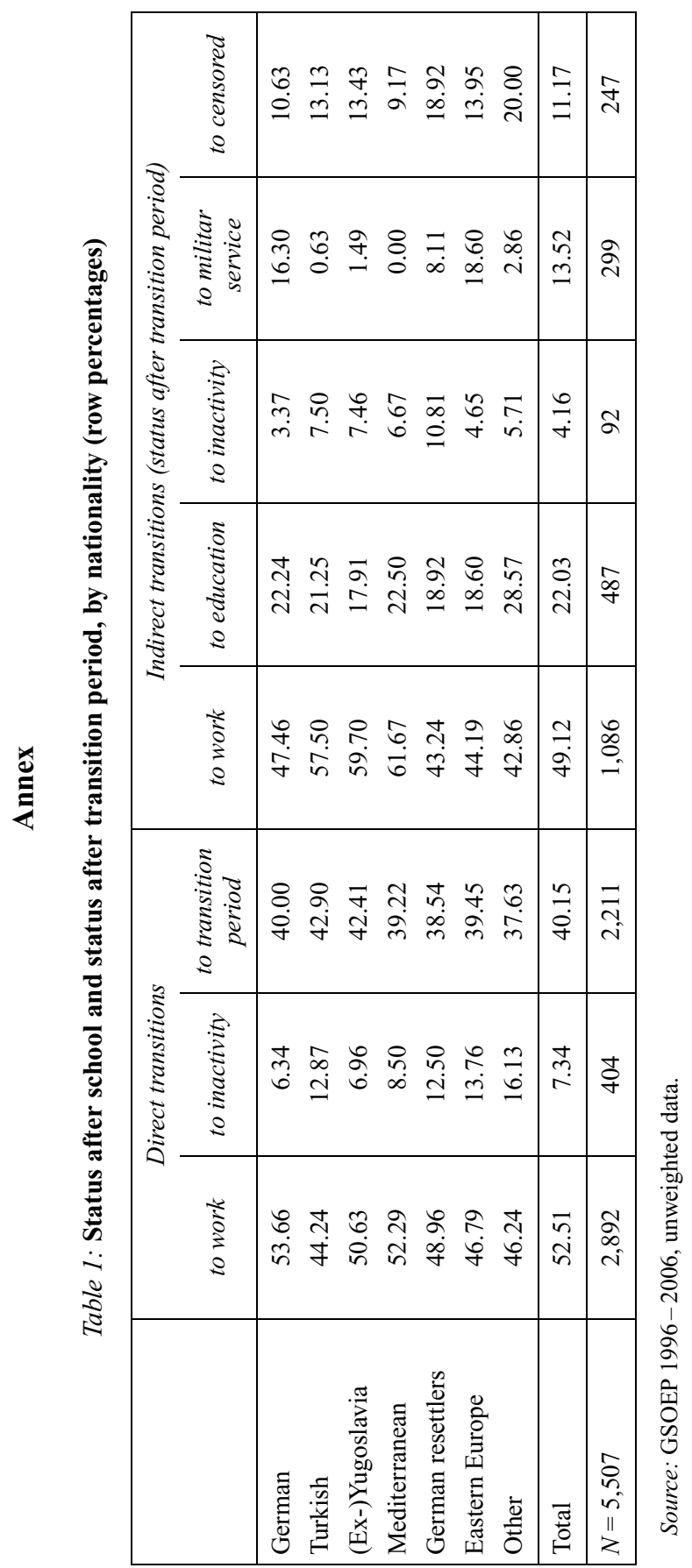

Schmollers Jahrbuch 129 (2009) 2 


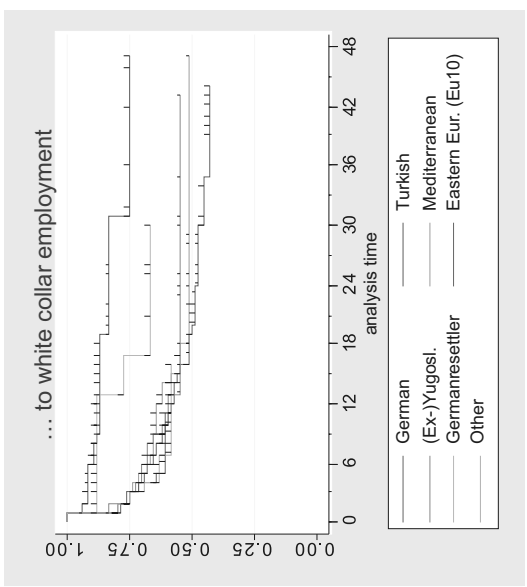

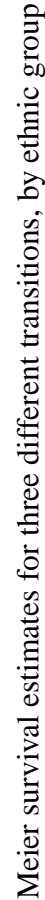
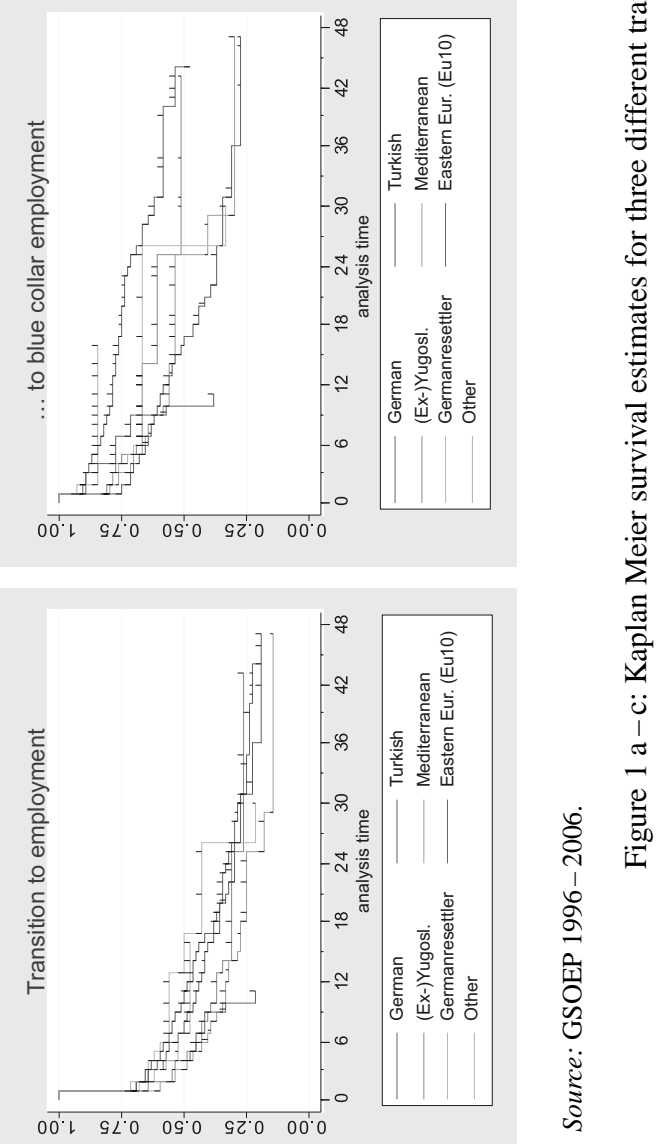

Schmollers Jahrbuch 129 (2009) 2 


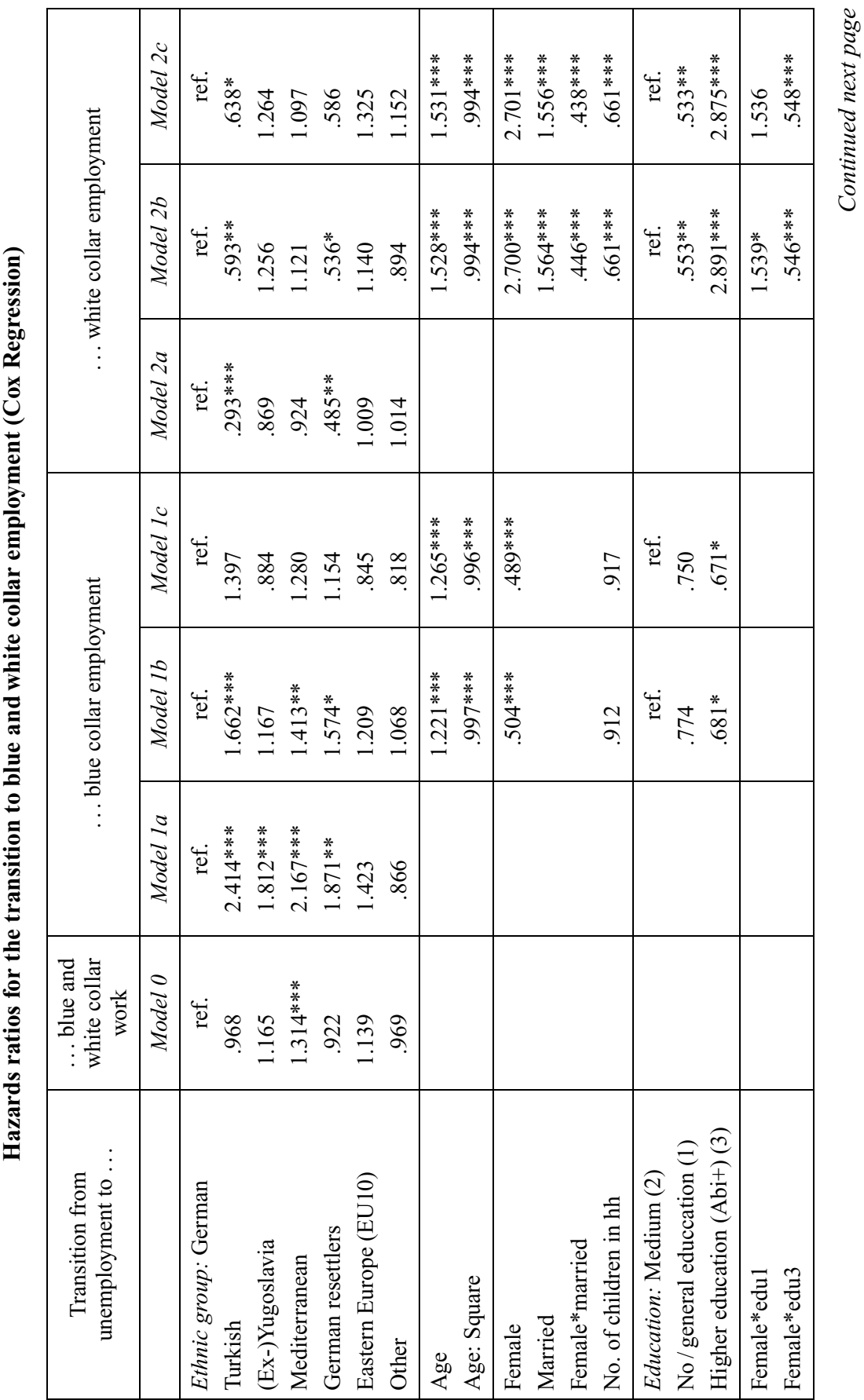

Schmollers Jahrbuch 129 (2009) 2 


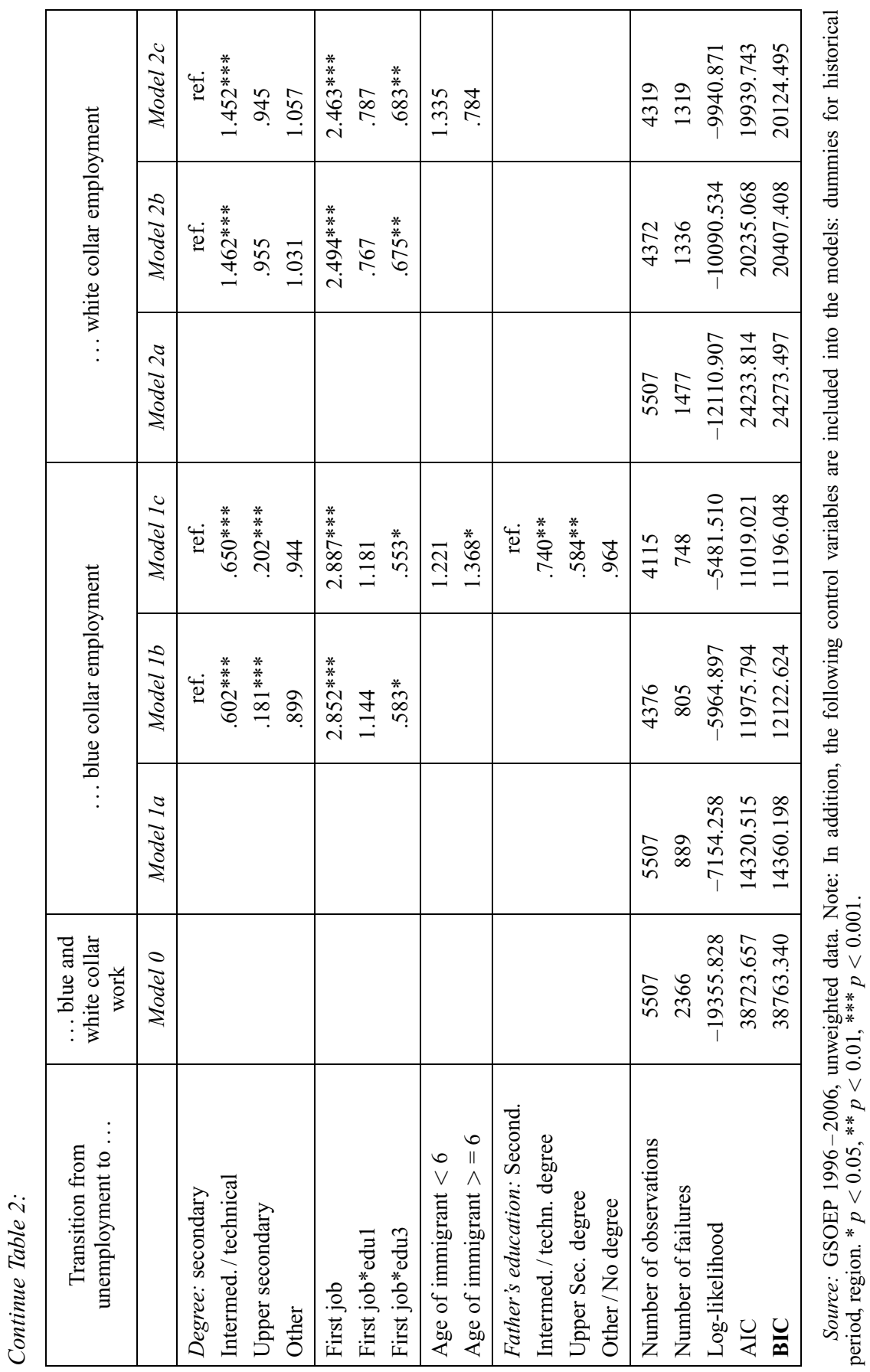

